\title{
The rise and fall of sexually transmitted diseases in Sweden
}

\author{
Stig Cronberg
}

\begin{abstract}
Syphilis appeared in Sweden in 1497. It was recognized as a sexually transmitted disease that rapidly spread in the upper classes and later to the poor. It ravaged the country in the eighteenth and nineteenth centuries. At that time the concept of venereal disease included all sexually transmitted diseases. Preventive measures were introduced. They were based on information, medical intervention and elimination of risk factors. Registration of hospitalised patients was introduced in the eighteenth century. The highest incidence of syphilis occurred during the First World War. In the last decade the incidence of sexually transmitted disorders has abruptly decreased. Thus the yearly incidence of gonorrhoea has decreased from 40000 to 500 cases. The law demands contact tracing with obligatory testing. People who deliberately expose others to risk may be condemned to isolation for an unrestricted time. This legislation has probably contributed less to the successful containment than the fact that information on aids and sexually transmitted diseases has reached all the population, and made it aware of the risks and produced changed behaviour, especially among prostitutes, homosexual men and drug addicts.
\end{abstract}

(Genitourin Med 1993;69:184-186)

\section{Early history 1497-1870}

Syphilis arrived in Sweden with German soldiers in 1497 and spread rapidly among the aristocracy. Among famous men attacked was the State Governor, Svante Nilsson, who died in 1512. ${ }^{1}$ From the upper classes the disease spread to the poor. It was called pox (pocker) or French disease. Its transmission by sexual intercourse was recognised in contemporary medical books. In the medieval period there were many public bath houses in the cities. These were now closed. The disease was treated with guayac or mercurials.

Little is known about the situation in the 17 th century, but as Sweden participated in many wars, the disease was probably quite common. In the eighteenth century venereal disease was widely spread and considered a great threat to public health. In a dissertation of 1705 Johan Linder discussed venereal disease and gave a good account of the different manifestations of syphilis. ${ }^{2}$ At this time other diseases, such as gonorrhoea, soft chancre, condyloma and genital carcinoma, were included in the unitary concept of venereal disease. Linder opposed the theory that syphilis was an ancient disease and believed that it had been imported from America and spread in the war at Naples. The recommended treatment was mercurials administered to the point of salivation.

A public health college was founded in 1721. The college recommended small county hospitals with $10-80$ beds and these were opened all over the country to isolate and treat patients with venereal disease. Nevertheless, the disease ravaged the country. Travellers, seamen and soldiers spread it far and wide. Taverns were "schools" for the dissemination of the disease. In $1843,45 \%$ of children in Stockholm were illegitimate, whereas the corresponding figure in the rest of the country was $8.5 \%$. The Medical College, a national group of physicians, suggested that the spread of venereal disease was due to public ignorance, lack of medical treatment and absence of preventive measures.

In the period, 1774-1792, popular books on prevention and treatment of venereal disease were published by Hallman, ${ }^{3}$ Odhelius ${ }^{4}$ and Wadström. ${ }^{5}$ The main modes of infection were considered to be transmission from mother to child, breastfeeding and sexual intercourse. The use of condoms was proposed to interrupt transmission by sexual intercourse. Soldiers were to be regularly inspected. Infected cases were to be reported and treated without cost if they were poor. Contact tracing was to be performed. Health certificates were recommended for travellers, soldiers, seamen, orphans, wet-nurses and people working in taverns. Marriage of contagious individuals was to be forbidden. Treatment was mandatory. Voluntary transmission of the disease to another person was to be punished. The old, popular idea that you might get rid of a venereal disease by infecting someone else was already strongly criticised by the experts.

Venereal disease was generally treated with mercurials, but at the beginning of the nineteenth century CG Osbeck introduced a modification of the method of the Danish physician Winslow. ${ }^{1}$ The cure lasted for 13 weeks and consisted of a diet involving reduced food intake, a herb, Antriscus silvestris, and, during the last three weeks, a low dose of mercurials. The cure was criticised by established physicians, since the herb was a cheaper substitute for the expensive Conium maculatum and was considered use- 




Figure 1 Annual incidence of syphilis in Sweden.

less. However, the cure was better tolerated by patients than conventional treatment with large doses of mercurials and it came into widespread use.

From 1797, all patients hospitalised were registered and 1000 patients a year were hospitalised at this time. Of 2512 patients admitted to hospital in Sweden in 1813, 1666 had venereal disease. In 1858,4269 patients were hospitalised with such a diagnosis. From 1822 , symptoms were also required to be reported, and it then became evident that $20 \%-40 \%$ presented with genital secretions suggesting infection with gonorrhoea. Genital ulcers suggesting syphilis or soft chancre were another common symptom. Condylomas occurred in $10 \%-25 \%$ of cases.

\section{The history from 1871}

From 1871 gonorrhoea was reported as a special disease entity. Soft chancre was distinguished from 1897. Academic chairs in syphilology had been established at that time and all medical students had to do a special course on venereal disease. At the end of the century, a mean of 4348 patients was annually hospitalised with sexually transmitted diseases: 1518 cases of syphilis, 1855 cases of gonorrhoea and 975 cases of soft chancre. Venereal disease was twice as common in men as in women. Half of the women were prostitutes aged 15-25 years.

Following the French example, weekly medical inspections of prostitutes were introduced in 1847, but it was not until more



Figure 2 Annual incidence of gonorrhoea in Sweden.



Figure 3 Annual incidence of soft chancre in Sweden.

strict regulations were introduced in 1859 that such inspections were efficiently executed. This law concerning "reglementation" of prostitution was controversial from the start. Most physicians considered regular inspections of prostitutes necessary to limit the spread of venereal disease. Women questioned why prostitutes were prosecuted when the behaviour of their clients was not punished. After extensive debate, the law was abolished in 1918. At the same time, other measures were introduced to interrupt disease transmission. The population was to be informed about the risk of getting sexually transmitted disease. Physicians had to instruct their patients on how to avoid transmitting the infection. Treatment was to be given free of cost. All cases were to be reported to health inspectors but the patient's name and address were not to be revealed. The source of infection was to be identified. Inspection and testing of potentially infected contacts were obligatory. Those refusing to cooperate could be punished.

Abstinence from extramarital sexual intercourse was considered the best prophylactic action. Condoms might be employed to interfere with the transmission of the disease, but recommending their use was seen to be acceptance of extramarital sexual relations. Advertising and information on use of condoms were therefore strictly forbidden by law in 1910. This law was not abolished until as late as 1938 .

Syphilis was treated with bismuth and Salvarsan, and gonorrhoea by local administration of silver salts. Gonorrhoeal keratitis was prevented by local instillation of silver salts in the eyes of all newborns. This procedure is no longer followed.

From 1912, all cases of sexually transmitted diseases were reported and registered. ${ }^{6}$ Syphilis reached a peak at the end of the First World War when an annual incidence of 4056 cases was reported in a population of about 6 million (fig 1). The annual incidence dropped to 375 in the 1930 s, but then rose to 1000 cases during and after the Second World War. With the advent of penicillin it dropped to 100 in the 1950 s, but then rose and stabilised around 400 cases a year. Syphilis now mainly affected homosexual 
men, but with their change of sexual behaviour in response to AIDS, the annual incidence has declined to fewer than 50 cases among indigenous Swedes.

The annual incidence of gonorrhoea remained stable at between 11000 to 16000 , from 1912 until 1960 (fig 2). It was thus not influenced by the introduction of sulphonamides or penicillin. With the arrival of contraceptive pills, the annual incidence rose to 30000 cases in 1966-1975. It declined to 23000 cases in 1976-1980. With the arrival of AIDS, the annual incidence rather abruptly declined to 500 cases in recent years.

Soft chancre has steadily declined so that we nowadays have fewer than seven cases each year (fig 3). Chlamydia trachomatis was recognised as an important genital infection at the end of the 1970s. A maximum of 40000 annual cases was reached at the end of the 1980s. The annual incidence has declined whenever testing has been performed for a long time. The disease has been included among those sexually transmitted diseases for which contact tracing is mandatory.

AIDS in Sweden has mainly affected homosexual men, haemophiliacs and, in Stockholm, intravenous drug users. Heterosexual transmission has been rare. It has mostly been associated with sexual contacts abroad or with foreigners in Sweden. A total of 600 cases of AIDS has been reported in Sweden. About 3000 individuals are known to be infected.

Prevention has been based on provision of information to the population and voluntary testing of people at risk. Anonymous testing, for a time forbidden, is presently allowed. All infected individuals must be reported and registered, but provision of full names is not required. Contact tracing must be performed. Testing is obligatory for contacts and it may be performed with the assistance of the police. Infected people who, despite instructions, deliberately expose others to risk may be condemned to isolation for an unrestricted time. About a dozen individuals have thus been isolated for periods up to several years. HIV-testing or health certificates are not required for visits to Sweden or for immigration.

Syringe exchange for intravenous drug users is at present not allowed. Just as was earlier the case with condoms, the Parliament believes that it gives a double message and amounts to acceptance of drug addiction. But an efficient syringe exchange programme in Malmö has been permitted to continue. Almost all intravenous drug users participate and there has been no case of new HIV-infection in this group for the last three years.

Other sexually transmitted diseases such as trichomonas and hepatitis B are also declining in incidence. Herpes virus and papilloma virus are still being spread but possibly less than before. It will be interesting to follow the movement in the incidence of cancer of the cervix uteri in future.

\section{Comparison with other countries}

The Swedes, being Lutheran Protestants, are accustomed to discuss biology and sexual relations in an undogmatic and free manner. They are also brought up with a free press and free universities. Information by press and television has therefore directly or indirectly reached all the population in an authoritative manner. Details of the Swedish population have been recorded for more than 200 years but as the country has never been occupied, people have confidence that the administration will handle delicate information in an acceptable manner. AIDS and STD prevention are therefore easier in Sweden than in many other countries.

\section{Present trends}

The rapid decline in sexually transmitted diseases in the last decade is the most exciting happening in their history in Sweden. Why has it occurred? Many explanations have been given, and many factors might have been responsible. At the beginning of the 1970 s, intramuscular injections against gonorrhoea were replaced by more convenient oral therapy. The number of sexual partners has decreased since the end of the 1960s. Contact tracing has become more efficient and rewarding. Homosexual men have changed their behaviour with the arrival of AIDS. This accounts especially for the decline in syphilis. Prostitutes have also become aware of the risks of sexually transmitted diseases, especially AIDS. They demand that their clients use condoms and the clients for the same reason are willing to use them. Personally, I feel that this might have been the most important change. Reservoirs of sexually transmitted diseases have suddenly become accessible to sanitary action after centuries of immunity.

For the future it is important to maintain respect for sexual transmission of serious disease. Recently we have seen examples of how negligence has led informed young homosexual men into becoming infected with HIV/AIDS.

1 Thyresson, N. Från Fransoser till AIDS. (From French dis ease to AIDS) Stockholm, Carlssons Bokförlag, 1991.

2 Linder, J. Dissertatio Medica de foeda lue dicta venerea. (Medical dissertation on luetic disease, also called venereal disease) Upsala Universitet 1705

3 Hallman, J. G. Lätt och minst kostsamt sätt at bota och forrekomma venerisk smitta hos gemene man i brist af veneriske cur-hus. (An easy and non-expensive way to cure and prevent (An easy and non in ordinive way to in the absere of herals) Stoclh in P. Hesseople 1774.

4 Odhelius, J. Underrättelse huru man, $i$ brist af läkare, kan bota sig sjelf for den farliga veneriska sjukdomen. (Information on self-treatment of the dangerous venereal disease in the absence of physicians) Stockholm Kungliga Patriotiska Sällskapet, 1775.

5 Wadström, J. Korta underrättelser för Allmoge och Tjenstefol om orsakerne til veneriska smittans kringspridande, faran of dess döljande samt sjukdomens allmännaste kännetecken. (Brief communications for ordinary people and servants concerning the reasons for the spread of venereal disease, the danger of its concealment and its most frequent symptoms) Linköping, G. Björn, 1796.

6 Official statistics are available fing Bakteriologiska Laboratorium, Stockholm, Sweden or from Statistiska Centralbyrån, Stockholm, Sweden. 